\title{
Ultraviolet radiation, vitamin D and multiple sclerosis
}

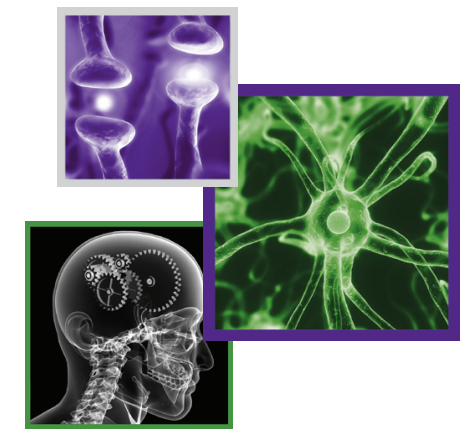

Robyn M Lucas ${ }^{*}, 1,2$, Scott N Byrne ${ }^{3}$, Jorge Correale ${ }^{4}$, Susanne Ilschner ${ }^{5}$ \& Prue H Hart $^{2}$

\section{Practice points}

- There is strong evidence from observational studies that low past sun exposure is associated with an increased risk of developing multiple sclerosis (MS).

- Lower sun exposure or lower vitamin D status have been linked to more severe MS, that is, more frequent relapses and more rapid progression to disability.

- Vitamin D supplementation trials for people with MS have shown improvement in immunological and MRI parameters, but with little convincing evidence of clinical benefit.

- Higher levels of sun exposure may have benefits for MS-related immune parameters through both vitamin D and non-vitamin D pathways.

- Exposure to ultraviolet radiation may result in immune tolerance that is beneficial for MS through upregulation of $T$ and $B$ regulatory cells, enhanced levels of cis-urocanic acid, alterations in dendritic cell trafficking as well as release of a range of other cytokines and chemokines.

- Trials of vitamin D supplementation and UVB phototherapy to prevent MS in people with clinically isolated syndrome are now underway.

There is compelling epidemiological evidence that the risk of developing multiple sclerosis is increased in association with low levels of sun exposure, possibly because this is associated with low vitamin D status. Recent work highlights both vitamin D and non-vitamin D effects on cellular immunity that suggests that higher levels of sun exposure and/or vitamin D status are beneficial for both MS risk and in ameliorating disease progression. Here we review this recent evidence, focusing on regulatory cells, dendritic cells, and chemokines and cytokines released from the skin following exposure to ultraviolet radiation.

Clues to etiological pathways often lie within the epidemiology of diseases. For multiple sclerosis (MS), the observation that the disease is more common with increasing distance from the equator led, over 50 years ago, to a link being drawn with variation in levels of ultraviolet radiation (UVR) [1]. Ensuing ecological and individual-level studies largely confirmed a link between lower sun exposure and increased risk of MS, and animal studies suggested the protective effect was mediated by vitamin D. However, the vitamin D precursor is not the only chromophore in the skin; a range of other

\section{KEYWORDS}

- B regulatory cells

- cis-urocanic acid

- dendritic cells $\bullet$ multiple

sclerosis $\bullet$ ultraviolet

radiation $\bullet$ vitamin $D$

'National Centre for Epidemiology \& Population Health, Research School of Population Health, The Australian National University,

Future : Medicine part of 
UV-induced products have biological effects likely to be relevant to MS. Here we provide an update on recent vitamin D-related research in MS, and situate this work within a broader consideration of low sun exposure as a risk factor for MS onset and progression.

\section{Biological effects of exposure to UV radiation}

We focus here on UVR, although solar radiation within the visible light and infrared (heat) spectra may also affect MS, with blue light induced inhibition of melatonin secretion having immunomodulatory effects [2], and heat causing a physiological worsening of symptoms in some people with MS (reviewed in [3]). Over $90 \%$ of the UVR at Earth's surface is within the UV-A wavelengths $(315-400 \mathrm{~nm})$ with the remainder shorter wavelength UV-B radiation $(280-315 \mathrm{~nm})$ [4]. UV-B has been considered the most biologically important because it is the main cause of DNA damage and the only part of the UV spectrum that initiates vitamin D synthesis in the skin. More recently, health effects of UV-A exposure are increasingly recognized $[5,6]$.

UVR is absorbed by a variety of chromophores in the skin each with maximum absorption at particular wavelengths. Thus 7-dehydrocholesterol is converted to pre-vitamin D, and trans-urocanic acid (UCA) is converted to cis-UCA, both with peak effectiveness in the UV-B wavelengths $(\sim 300 \mathrm{~nm})$. Nitric oxide is released from the skin with peak effectiveness in the UV-A waveband; DNA damage ensues from the formation of cyclobutane pyrimidine dimers (UV-B) as well as oxidative stress (UV-A) (reviewed in [7]).

\section{Links between sun exposure, vitamin D \& MS: evidence from epidemiology - MS risk}

The presence of a latitude gradient in the incidence, prevalence and mortality of MS is welldescribed $[1,8-10]$. The gradient persists in some locations [10] but has disappeared over recent years in others [11], possibly because reduced sun exposure as a consequence of public health messages has resulted in an increase in MS incidence in low latitude locations that now approximates that seen in higher latitude locations. The correlation with ambient UVR is stronger than that with latitude [1], but other factors co-vary with latitude and UVR levels, for example temperature. Thus the ecological correlation is supportive rather than definitive evidence of a link between MS and sun exposure and/or vitamin $\mathrm{D}$.

Several reviews have noted the largely consistent evidence that people with MS report lower levels of past sun exposure compared to those without MS (e.g., [12]), and that people who develop MS have lower levels of serum 25-hydroxyvitamin D (25OHD, the usual measure of vitamin D status) than control participants without MS [13,14]. 'Past sun exposure' has been interpreted as being a proxy for past vitamin D status; importantly, serum $25 \mathrm{OHD}$ levels are equally a proxy for recent sun exposure. Because of the close links between sun exposure and vitamin D status, it is difficult in observational studies to separate whether any protective effect for MS is due to sun exposure, vitamin D, or some combination [15].

Ecological studies have also shown a marked season of birth effect in MS, consistent with increased risk associated with lower sun exposure/vitamin $\mathrm{D}$ in the late first trimester of pregnancy. There is an opposite pattern for months, that is, equivalent for seasons, in the northern [16] and southern hemispheres [17]. This raises the possibility that early life (in utero) sun exposure can alter susceptibility to MS development as an adult. Observational studies provide some support to the importance of low sun exposure in early life for MS risk. For example, studies report highest MS risk in association with low sun exposure from birth to 5 years [18], or in adolescence [18-20]. However, a recent study of $25 \mathrm{OHD}$ levels at birth (measured from neonatal blood spots) showed no association with later risk of MS [21]. The null finding could be real, that is, no effect of vitamin $\mathrm{D}$ during pregnancy, or related to measurement issues in older blood spots. In this study 25OHD levels were higher in more recent blood spots [21], yet a previous study has shown that $25 \mathrm{OHD}$ levels in pregnant women decreased over the same time period in Sweden [22].

A case for a specific role for vitamin D (rather than sun exposure) is supported by studies showing that higher dietary intake, both of the mother during pregnancy [23] and of the adult participant [24], is protective for MS onset. However, here the likely accuracy of the dietary data and the dose estimates inferred from supplements reportedly taken some years previously, needs to be considered.

Support for a specific causative role for vitamin D deficiency in MS pathogenesis could 
also come from genetic studies, either where MS risk is related to genetic determinants of synthesis, conversion to the active form, or catabolism, or genetic variants of the vitamin $\mathrm{D}$ receptor (VDR). Here the evidence is mixed (reviewed in [25]). A vitamin $\mathrm{D}$ response element has been identified in the promoter region of the $H L A-D R B 1^{*} 1501$ gene, suggesting a possible role of vitamin $\mathrm{D}$ in regulating the genetic locus that is most strongly implicated in MS risk [26]. SNPs within the CYP27B1 (the 1- $\alpha$-hydroxylase enzyme converting $25 \mathrm{OHD}$ to the active form of vitamin $\mathrm{D}, 1,25(\mathrm{OH})_{2} \mathrm{D}$ ) [27] and CYP24A1 (catabolising vitamin $\mathrm{D}$ metabolites) genes have been identified as being associated with MS risk [28] and VDR binding sites are significantly enriched near MS-associated genes [29]. Studies of SNP variants of the VDR gene in association with MS risk show no association [30,31], or associations that are inconsistent across the main VDR alleles [32-34]. In a recent meta-analysis, only the AA and FF genotypes of the ApaI and FokI alleles (respectively) were associated with increased MS risk [35]. Vitamin D binding protein (DBP) level and genotype are determinants of 25OHD levels [36,37]: Rinaldi and colleagues report higher levels of circulating DBP in people with MS [38], while Smolders and colleagues report no difference compared with unaffected controls [39].

\section{- Progression of disease in MS \& disability} Many studies note lower 25OHD levels in more severe disease; here it is difficult to tease out the direction of the temporal associations. Severe vitamin D deficiency $(<23.7 \mathrm{nmol} / \mathrm{l})$ has been associated with increased risk of conversion from clinically isolated syndrome (CIS) to clinically definite MS (CDMS), with no change in risk associated with higher levels of $25 \mathrm{OHD}$ [40]. In prospective studies, higher 25OHD levels predicted reduced MS relapse activity, a slower rate of progression [41] and lower disability $[42,43]$ but were not linked to the risk of postpartum relapse [44]. A recent metaanalysis confirmed that people with MS have lower 25OHD levels, but did not shed light on the causal direction of the effect [45]. The association between 25OHD level and relapse in MS is reported to vary according to genotype (PKC family [46], ZNF767, CYP24A1 [47]) and $25 \mathrm{OHD}$ level may modify the effectiveness of IFN $-\beta$ treatment [48]. IFN- $\beta$ therapy appears to increase the effect of sun exposure on the serum $25 \mathrm{OHD}$ level [48], although more recent work indicates that this is dependent on SNPs within the WT1 gene that is a downstream component of the $V D R$ [49]. These findings suggest that IFN- $\beta$ works at least in part via a vitamin $D$ pathway [50], although a very recent study found no interaction between IFN- $\beta$ treatment and vitamin D status for MRI activity or markers of inflammation [51].

Few studies have sought to distinguish the effects of sun exposure from those of vitamin D on disability in people with MS. In one such study, both higher levels of sun exposure and higher 25OHD levels were associated with lower risk of developing severe MS, although the effect was stronger for sunlight than vitamin D [52]. Higher levels of sun exposure, but not $25 \mathrm{OHD}$ levels, were associated with low fatigue scores and fewer depressive symptoms in one study [53], but the odds of depression were markedly reduced in people with MS who took a vitamin D supplement in another study [54].

Randomized controlled trials present an opportunity to distinguish vitamin $\mathrm{D}$ benefits from those of sun exposure. Here, despite the considerable evidence of lower 25OHD levels in people with more active MS, vitamin D supplementation trials have shown disappointing results for disease activity in people with MS [12,55]. Issues of sample size, inadequate dose of vitamin $\mathrm{D}$ and nonrandomization may explain the conflicting findings [55]. One small pilot study has shown that high dose vitamin D supplementation may decrease progression from optic neuritis to MS [56], and, in a recent randomized, double-blind placebo controlled trial using a vitamin D analogue, alfacalcidol, treatment was associated with reduced fatigue score, improvement in quality of life and fewer relapses [57]. Larger clinical trials of vitamin D supplementation are currently underway for both onset and disease activity in MS [58,59]. There has been only one study to-date of UV-B phototherapy in people with MS [60]. The treatment induced higher levels of active vitamin D, and improved wellbeing, but had no effect on relapse rate or disability score.

Overall, the evidence from epidemiology is suggestive of beneficial effects of higher vitamin D status (or avoidance of deficiency) and/or higher levels of sun exposure for both MS risk and disease progression. There is considerable 
mechanistic support for important roles for the benefits of sun exposure for MS, through both vitamin $\mathrm{D}$ and non-vitamin $\mathrm{D}$ pathways.

\section{UV activation of regulatory cells}

The autoimmune pathology of MS is complicated and only partially understood. The disease appears to be caused largely by unregulated activation of cell-mediated immune responses that target the CNS [28]. UV irradiation results in suppression of cell mediated immunity, in part via the activation of regulatory cells. One of the first UV-regulatory cells to be described was the suppressor $\mathrm{T}$ cell (now called regulatory $\mathrm{T}$ cell $\left[\mathrm{T}_{\mathrm{Reg}}\right]$; reviewed in [6]]). In mice, topical application of $1,25(\mathrm{OH})_{2} \mathrm{D}_{3}$ activates and enhances the suppressive activity of $\mathrm{CD} 4^{+} \mathrm{CD} 25^{+} \mathrm{T}_{\text {Regs }}$ in skindraining lymph nodes [62]. Topical treatment with $1,25(\mathrm{OH})_{2} \mathrm{D}_{3}$ also led to local immune suppression in human study participants [63]. A similar approach using calcipotriol, a lower calcaemic analog of $1,25(\mathrm{OH})_{2} \mathrm{D}_{3}$, has been put to therapeutic use in the treatment of autoimmune skin disorders such as polymorphic light eruption [64]. In humans, a rise in the baseline proportions of $T_{\text {Regs }}$ following the first exposure to therapeutic narrowband UV-B was associated with an initial increase in 25OHD levels [65]. This association between 25OHD level and $\mathrm{T}_{\text {Regs }}$ was lost with repeated exposure suggesting that low 25OHD levels limit the number of $\mathrm{T}_{\text {Regs }}$. Human $\mathrm{T}_{\text {Regs }}$ express functional vitamin $\mathrm{D}$ receptors [66]. Somewhat paradoxically, although exposure to $1,25(\mathrm{OH})_{2} \mathrm{D}_{3}$ ex vivo suppressed $\mathrm{T}_{\text {Reg }}$ proliferation, the $1,25(\mathrm{OH})_{2} \mathrm{D}_{3}$-stimulated $\mathrm{T}_{\text {Regs }}$ produced significantly more immune suppressive IL-10 [66]. Thus UVR, concurrently or independently of vitamin D may exert its immune modulatory effects by enhancing the suppressive function of $\mathrm{VDR}^{+} \mathrm{T}_{\text {Regs }}$.

In MS patients, $1,25(\mathrm{OH})_{2} \mathrm{D}_{3}$, as well as UV irradiation, activated $T_{\text {Regs }}$ possibly through an indoleamine 2,3-dioxygenase-mediated pathway [67]. In another study, in MS patients exposed to therapeutic doses of narrowband UV-B radiation, there was a predicted rise in serum 25OHD levels from a very low base [60]. While this was associated with a concomitant rise in the percentage of inducible $T_{\text {Regs }}$, no change in the neurological status, the relapse rate, or the disability score was observed [60]. It therefore remains to be determined whether change in $T_{\text {Regs }}$ explains the protective effect of UVR (and/or vitamin D) in MS.
In UV-exposed skin, a major cellular target of vitamin $\mathrm{D}$ and its precursor molecules is likely to be dermal mast cells. Recently it was shown that mouse and human mast cells can convert $25 \mathrm{OHD}_{3}$ to $1,25(\mathrm{OH})_{2} \mathrm{D}_{3}$ through CYP27B1 catalytic activity [68]. In response to $1,25(\mathrm{OH})_{2} \mathrm{D}_{3}$ itself, mouse mast cells are activated to produce significant amounts of immune regulatory IL-10 [69] which is likely to explain why mice deficient in mast cells are resistant to the immune suppressive effects of UV-B [70]. UV-B irradiation has a further role in transmitting the suppressive signal generated in the skin, by activating mast cells to migrate to the skin-draining lymph nodes. There, the recently arrived IL-10-secreting mast cells make intimate contacts with B cells [71] and suppress antibody class-switch recombination and affinity maturation in germinal centers [72]. As mast cells are known to mediate the activation of $\mathrm{T}_{\text {Regs }}[73]$ and $\mathrm{B}$ cells [74], it is thought this is a major mechanism by which UVR, and possibly vitamin $\mathrm{D}$, are working to suppress adaptive immune responses.

In addition to UV-T $T_{\text {Regs }}$, another major regulatory cell activated by UV irradiation is the B cell $[75,76]$. While traditionally responsible for mediating humoral immunity via their production of antibodies, it has become increasingly clear that subsets of IL-10-producing B cells can also exert potent immune regulatory functions (reviewed in [77]). In mice, these so-called ' $U V-B_{\text {Regs }}$ ' express high levels of MHC class II, B220 (CD45R) and IL-10. They are found only in the skin-draining lymph nodes in UV-Bexposed mice [78] and can be used to adoptively transfer immune suppression from a UV-exposed mouse to an unirradiated host [75,76]. UV-B $\mathrm{B}_{\text {Regs }}$ require signals through Platelet Activating Factor (PAF) and serotonin (5HT) receptors to be activated [76]; whether this also involves cis-UCA (discussed below) [79] remains to be determined. Activated, but not freshly isolated, naive B cells express functional VDRs [80] and stimulating human $\mathrm{B}$ cells with $1,25(\mathrm{OH})_{2} \mathrm{D}_{3}$ ex vivo leads to enhanced production of immune regulatory IL-10 [81]. This is highly relevant to MS as there is a strong link between B-cell production of IL-10 and protection from CNS autoimmunity [82]. Indeed, MS patients in relapse had significantly fewer (5-6 times lower) circulating naive (CD27-) IL-10-producing B cells compared with those in remission [83]. Importantly, when these relapse patients remitted, the numbers of ' $\mathrm{B}_{\text {Regs }}$ ' 
returned to normal. However, no correlation between the percentage of $B_{\text {Regs }}$ and vitamin $D$ status was observed [83]. It is possible that UVR itself is activating $B_{\text {Regs }}$ (maybe through PAF and 5HT), and that vitamin D may be targeting other, pathogenic, B cell subsets. Indeed, in vitro, vitamin $\mathrm{D}$ not only interferes with plasma cell differentiation and IgG secretion, it also inhibits the development of post-switched memory B cells [80]. This too is likely to be highly relevant to MS patients, as high affinity, class-switched antibodies are thought to be a major pathological driver of both the initiation and progression of MS [84]. Rather disappointingly, patients with relapsing-remitting MS who were provided with high-dose vitamin $\mathrm{D}_{3}$ supplementation for 12 weeks showed no significant change in B-cell differentiation, isotype switching, or plasma $\mathrm{B}$-cell activating factor levels [85]. Thus, the role of UVR and/or vitamin D in targeting B cells in vivo is still unclear.

\section{Dendritic cells \& macrophages}

In MS, the tight regulation of the balance between immunity and tolerance is disturbed. Dendritic cells (DCs) are central to maintaining this balance; they direct sustained adaptive immunity by stimulating autoreactive $\mathrm{T}$ lymphocytes [86]. The DC- $\mathrm{T}_{\mathrm{Reg}}$ interaction is also important in the CNS [87]. Dendritic cells are increased in the CNS in the early phases of MS, and during relapse, highlighting their ongoing 'director' role [88]. Thus, it is likely that it would be beneficial for MS control if the numbers and/or the immunogenicity of DCs were reduced in the CNS.

There is an extensive literature showing that UVR-induced vitamin $\mathrm{D}_{3}$ may stimulate the induction of tolerogenic DCs [89]. Contrary to expectations, experimental allergic encephalomyelitis (EAE), the mouse model of MS, is less intense (rather than more as would be expected) in vitamin $\mathrm{D}$-deficient animals [90,91]. Also reductions in EAE by $1,25(\mathrm{OH})_{2} \mathrm{D}_{3}$ administration have been attributed to hypercalcaemia [92]. However, an involvement of vitamin $\mathrm{D}$ in tolerogenic DC induction and controlled immunity in the CNS of MS patients is supported by other studies. Dendritic cells from MS patients express higher levels of CLEC16A; the gene is located within a susceptibility locus for MS [93]. Importantly, CLEC16A is a direct regulator of the HLA class II pathway and its expression is reduced by $1,25(\mathrm{OH})_{2} \mathrm{D}_{3}$ exposure [93].
The $C Y P 27 B 1$ gene is predominantly expressed in DCs [94]. The CYP27B1 variant that is associated with an increased risk of MS is expressed at lower levels in DCs compared with the protective variant; this is likely to translate to reduced tolerogenic function of these DCs [94], providing a pathway to increased MS risk. Responses to $1,25(\mathrm{OH})_{2} \mathrm{D}$ may also be reduced in DCs from MS patients [95].

Other studies have shown an effect of UV irradiation of skin on the development of tolerogenic DCs, by vitamin D-independent pathways $[60,96,97]$. UV irradiation, delivered before and during sensitization to an encephalitogenic peptide, reduced the time to onset of EAE and the intensity of disease expression [60]. Six days after UV irradiation and before clinical disease onset, DCs in the spleen expressed lower levels of co-stimulatory CD80 and CD86, and increased IL-10 and other tolerogenic markers [60]. When encephalitogenic $T$ cells were injected into UV-irradiated mice, they were programmed to be less pathogenic, potentially directed by the activity of tolerogenic DCs. Furthermore, there was an increased number of $\mathrm{T}_{\text {Regs }}$ in the CNS of UV-irradiated mice at the time of disease expression [60]. Induction of prostaglandin $\mathrm{E}_{2}$ and vitamin $\mathrm{D}_{3}$ in the skin following UV irradiation was proposed to contribute to expansion of $T_{\text {Regs }}$ and development of tolerogenic DCs [60]. UVRinduced prostaglandin $\mathrm{E}_{2}$ also initiates signals delivered to DC progenitors in the bone marrow such that their daughter cells have reduced immunogenic properties in the periphery for priming new immune responses [98-100]. In fully-engrafted chimeric mice (16 weeks), the UV-induced effect remained strongly with the DC progenitors in bone marrow suggesting a long-lasting effect that may be relevant to EAE and MS control [99,100].

Most mechanistic conclusions have come from studies in mice. UV-induction of tolerogenic DCs by both vitamin D-dependent and -independent pathways requires confirmation in trials of vitamin D supplementation and UV-B phototherapy for patients with MS.

Phagocytic macrophages and microglia are prominent in MS lesions [86]. It has been proposed that monocyte-derived phagocytes initiate demyelination and oxidative stress while those from microglia are less inflammatory, clear cellular debris and promote repair. Macrophages in chimeric mice engrafted with bone marrow cells from $\mathrm{PGE}_{2}$-administered mice migrated poorly towards an inflammatory stimulus in the 
peritoneal cavity; this reduced migration suggests another regulatory mechanism induced by UV irradiation for potentially controlling MS initiation and progression [100].

\section{UV-induced production of cis-urocanic acid}

Urocanic acid (UCA) is one of the major cutaneous absorbers of UVR, with absorption particularly within the UV-B wavelengths [101]. It is formed as the trans isomer from histidine in the outermost layers of the epidermis where histidase is activated. As urocanase, the enzyme responsible of its degradation, is absent from skin, UCA accumulates in that site. On UV irradiation, photoisomerization from trans- to cis-UCA takes place in a dose-dependent fashion until the photostationary state is reached, with approximately equal quantities of the two isomers. Upon photoisomerization, cis-UCA is distributed systemically, and is excreted in the urine; it conveys both cutaneous and systemic immunosuppression [102].

Immunomodulatory effects on contact hypersensitivity, delayed type hypersensitivity, tumor antigen presentation and allograft reaction have all been reported for $c$ is-UCA [103-106]. Moreover, its systemic immunosuppressive effects have been demonstrated through its ability to reduce the severity of chemically-induced colitis [107]. In MS, a recent study demonstrated that plasma levels of cis-UCA were significantly lower in patients with relapsing remitting MS compared to healthy controls, but there was no relationship between cis-UCA levels and disease remissions or exacerbations [108]. In in vitro studies with PBMCs cultured in the presence of $c i s$-UCA, several immunoregulatory effects were observed, namely: enhanced IL-10 secretion and inhibition of IFN- $\gamma$ production; induction of $\mathrm{CD} 4^{+} \mathrm{CD} 25^{+} \mathrm{FoxP} 3^{+}$regulatory $\mathrm{T}$ cells; and reduced antigen presenting capacity by DCs [108]. Likewise, in vitro experiments demonstrated that mouse spleen cells cultured in the presence of cis-UCA significantly increase the production of IL-10, and decrease the production of IL- 2 and IFN- $\gamma$. In these experiments, activated $\mathrm{CD}^{+} \mathrm{T}$ cells appeared to be the principal cells responding to cis-UCA [109]. Nevertheless, it seems likely that people with MS may engage less in outdoors activities and thus will have lower sun exposure than controls. Thus it is possible that the lower cis-UCA in MS patients may be a consequence of the disease rather than a contributing risk factor.

Previous evidence suggests that cis-UCA and 5HT are structurally similar and share the same receptor; antagonists against $5 \mathrm{HT}_{2 \mathrm{~A}}$, one of the receptors expressed predominantly by autoreactive $\mathrm{T}$ cells, also blocked cis-UCAinduced immune suppression [79]. In other studies, cis-UCA bound to a receptor on human monocytes that was not the $5 \mathrm{HT}_{2 \mathrm{~A}}$ receptor [110].

Table 1. Summary of potential pathways whereby exposure to UV radiation may ameliorate the risk of multiple sclerosis.

\begin{tabular}{|c|c|c|}
\hline UV-induced product & Source of evidence & Proposed mechanism of action \\
\hline Vitamin D & $\begin{array}{l}1,25(\mathrm{OH})_{2} \mathrm{D} \text { ameliorates } \mathrm{EAE} \text {; high } 25 \mathrm{OHD} \text { levels } \\
\text { associated with reduced risk of MS in human studies; } \\
\text { genetic studies implicate vitamin D response } \\
\text { elements in key MS genes; vitamin D pathway genes } \\
\text { implicated in MS risk }\end{array}$ & $\begin{array}{l}\text { - Upregulation of T regulatory cells } \\
\text { - } 1,25(\mathrm{OH})_{2} \mathrm{D} \text {-stimulated } \mathrm{T}_{\text {regs }} \text { and mast cells produce more } \\
\text { IL-10 } \\
\text { - In vitro vitamin D metabolites inhibit development of } \\
\text { post-switched memory B cells } \\
\text { - Stimulates induction of tolerogenic DCs }\end{array}$ \\
\hline Prostaglandin $\mathrm{E}_{2}$ & Animal and in vitro studies & $\begin{array}{l}\text { - Reduces immunogenic properties of DCs } \\
\text { - Regulates myeloid progenitor cells in the bone marrow } \\
\text { so that daughter cells are less immunocompetent }\end{array}$ \\
\hline cis-UCA & $\begin{array}{l}\text { In vitro studies show immunoregulatory effects; lower } \\
\text { levels of cis-UCA in people with MS compared to } \\
\text { controls }\end{array}$ & $\begin{array}{l}\text { - Enhances IL-10 secretion } \\
\text { - Induction of } \mathrm{T}_{\text {reg }} \text { cells } \\
\text { - Reduces antigen-presenting capacity of DCs }\end{array}$ \\
\hline Cytokine release & See Table 2 & \\
\hline Platelet activating factor & Animal studies [116] & $\begin{array}{l}\text { - Activates mast cells to migrate to the skin-draining } \\
\text { lymph nodes with suppression of antibody class-switch } \\
\text { and activation of } \mathrm{T}_{\text {reg }} \text { and } \mathrm{B}_{\text {reg }}\end{array}$ \\
\hline Unknown & & $\begin{array}{l}\text { - Induction of tolerogenic dendritic cells (lower levels of } \\
\text { CD80 and CD86 and increased IL-10) }\end{array}$ \\
\hline
\end{tabular}




\begin{tabular}{|c|c|c|c|}
\hline Cytokine & UV-induced trigger & Main cutaneous source & Possible role in MS \\
\hline \multicolumn{4}{|c|}{ Upregulated } \\
\hline IL-10 & $\begin{array}{l}\text { DNA damage } \\
\text { Vitamin D }\end{array}$ & $\begin{array}{l}\text { Epithelial cells } \\
\text { Dendritic cells } \\
\text { Mast cells }\end{array}$ & 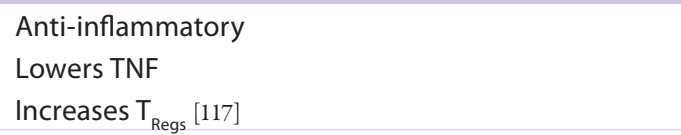 \\
\hline IL-1 $\beta$ & ATP? Caspase? [118] & $\begin{array}{l}\text { Macrophages } \\
\text { Keratinocytes }\end{array}$ & $\begin{array}{l}\text { Proinflammatory } \\
\text { Increases permeability of the blood-brain barrier [119] }\end{array}$ \\
\hline IL-6 & DNA damage & $\begin{array}{l}\text { Keratinocytes }[120] \\
\text { T-cells } \\
\text { Macrophages } \\
\text { Fibroblasts }\end{array}$ & $\begin{array}{l}\text { Proinflammatory } \\
\text { Increases Th17 [121] }\end{array}$ \\
\hline IL-8 & $\begin{array}{l}\text { UV-B } \\
\text { Topical 1,25(OH)D inhibits release }[124]\end{array}$ & $\begin{array}{l}\text { Fibroblasts [122] } \\
\text { Keratinocytes } \\
\text { Mast cells }\end{array}$ & Reduced by IFN- $\beta$ treatment $[123]$ \\
\hline GM-CSF & DNA damage & $\begin{array}{l}\text { T cells } \\
\text { Macrophages } \\
\text { Keratinocytes [126] }\end{array}$ & Associated with relapses [125] \\
\hline TNF & IL-1 & $\begin{array}{l}\text { Macrophages } \\
\text { Mast cells } \\
\text { T cells } \\
\text { Keratinocytes [127] }\end{array}$ & Proinflammatory \\
\hline IL-33 & Platelet activating factor & $\begin{array}{l}\text { Fibroblasts [114] } \\
\text { Keratinocytes [114] }\end{array}$ & $\begin{array}{l}\text { Paradoxically elevated in MS patients [128] } \\
\text { Attenuates EAE by suppressing IL-17 and IFN [129] }\end{array}$ \\
\hline Downregu & & & \\
\hline IFN- $\gamma$ & $\begin{array}{l}\text { Cytokine signaling molecules } 1 \text { and } \\
3 \text { [130] }\end{array}$ & Keratinocytes & Macrophage/microglia stimulation \\
\hline $\mid 1-17 / 23$ & Transcriptional modulation, IL-6 [118] & $\begin{array}{l}\text { Th } 17 \text { cells } \\
\text { Keratinocytes }\end{array}$ & $\begin{array}{l}\text { Expressed in brain lesions of MS patients; induces } \\
\text { expression of inflammatory genes in astrocytes [131] }\end{array}$ \\
\hline
\end{tabular}

Interestingly, in normal human epidermal keratinocytes, and in the human $\mathrm{T}$ lymphocyte line Jurkat cells, cis-UCA and UV-B irradiation induced the expression of galectin-7, which in turn upregulated apoptosis, and inhibited the production of IL-2 and IFN- $\gamma$ [111]. Overall, these observations provide further evidence that sunlight exposure affects autoimmune disorders like MS, through several different modulatory pathways.

\section{UV-induced release of cytokines and chemokines}

UV irradiation of the skin causes release of a range of chemokines and cytokines (see Table 1), including IL-1 $\beta$, IL-6, IL-8, IL-10, IL-33, IFN$\gamma$, GM-CSF, TNF, CCL4 and CCL5 [112]. UV-induction of CXCL12 in both the skin and draining lymph nodes is particularly important for UV-induced immune suppression [71]. While it remains to be determined whether $1,25(\mathrm{OH})_{2} \mathrm{D}$ is responsible for modulating expression of this chemokine, $1,25(\mathrm{OH})_{2} \mathrm{D}_{3}$ upregulates the CXCL12-receptor CXCR4 [113]. Similarly, while evidence is lacking that $U V$-induced upregulation of IL-33 is vitamin D-mediated [114], culture with $1,25(\mathrm{OH})_{2} \mathrm{D}_{3}$ enhances the production of soluble ST2, the receptor for IL-33 [115]. When $\mathrm{CD}_{4}{ }^{+} \mathrm{T}$ cells from patients with MS were cultured in the presence of $1,25(\mathrm{OH})_{2} \mathrm{D}_{3}$, there was an increased number of IL-10 producing cells, as well as downregulation of IL-6 and IL-17-secreting T cells [67]. Thus, $1,25(\mathrm{OH})_{2} \mathrm{D}_{3}$ either directly or indirectly can modulate the response of immune cells to UV-induced cytokines and chemokines.

Sensory nerves innervating the skin release substance $\mathrm{P}(\mathrm{SP})$, neurokinin $\mathrm{A}$, neuropeptide $\mathrm{Y}$ and calcitonin gene-related peptide (CGRP), principally in response to UV-induced release of cis-UCA [132]. Neuroendocrine hormones such as proopiomelanocortin, $\alpha$-melanocyte stimulating hormone $(\alpha-\mathrm{MSH}), \gamma-\mathrm{MSH}$ and $\beta$-endorphin are also released from a variety of cells in the skin [133]. 
Many of these chemokines and cytokines may act as mediators of immunity and inflammation within the skin, but less is known about their systemic effects on immune function. However, both CGRP and $\alpha$-MSH have been implicated in UV-induced suppression of delayed type hypersensitivity and cutaneous hypersensitivity responses. CGRP reduces the density of the epidermal antigen presenting cells and impairs their function as well as that of dermal DCs [133]. Additional work will be required to map out systemic effects, if any, on immune function that may be relevant to MS risk and disease progression [132].

\section{Conclusion}

There is compelling evidence that suggests that higher levels of sun exposure are associated with decreased risk and disease activity in MS, probably through both vitamin $\mathrm{D}$ and non-vitamin $\mathrm{D}$ pathways. UVR is absorbed by a number of chromophores in the skin. Absorption by DNA causes UV-signature mutations and when the damage surpasses repair processes, skin cancers may result. UV irradiation of the skin is the principal source of vitamin D for many people, and there is a large body of epidemiological, genetic and laboratory research that indicates a protective role for higher vitamin $\mathrm{D}$ levels, although the effects may be modest. There is now a growing body of work exploring mechanisms whereby other chemicals released following sun exposure can affect immune cell trafficking, or regulatory $\mathrm{B}$ and $\mathrm{T}$ cells to modulate MS risk. Substantiating and quantifying the effect of these mediators of MS risk and disease progression will be important for potential therapeutic and prevention initiatives.

\section{Future perspective}

Recognition of multiple pathways whereby exposure to UVR may affect the development of MS could mark the beginning of prevention activities through modulation of an environment risk factor and the development of new therapeutic compounds. The vitamin D star seems to be waning, despite considerable genetic evidence that vitamin D has a role in MS risk. Perhaps it is only one part of a more complex picture. New intervention trials, undertaken in parallel, of vitamin D supplementation and UV-B phototherapy, should provide more definitive evidence - at least for the risk of MS following CIS. A finding that sun exposure, through the entirety of its effects, does have clinical significance as an immunomodulator for the development of MS, offers one of the few opportunities to modify disease risk for MS.

\section{Financial \& competing interests disclosure}

The authors have no relevant affiliations or financial involvement with any organization or entity with a financial interest in or financial conflict with the subject matter or materials discussed in the manuscript. This includes employment, consultancies, honoraria, stock ownership or options, expert testimony, grantsor patents received or pending, or royalties.

No writing assistance was utilized in the production of this manuscript.

\section{Open access}

This work is licensed under the AttributionNonCommercial-NoDerivatives 4.0 Unported License. To view a copy of this license, visit http://creativecommons.org/ licenses/by-nc-nd/4.0/

\section{References}

Papers of special note have been highlighted as: - of interest; $\bullet$ of considerable interest

1 Acheson ED, Bachrach CA, Wright FM. Some comments on the relationship of the distribution of multiple sclerosis to latitude, solar radiation and other variables. Acta Psychiatr. Scand. Suppl. 35(S147), 132-147 (1960).

2 Lucas RM, Ponsonby AL. Considering the potential benefits as well as adverse effects of sun exposure: can all the potential benefits be provided by oral vitamin D supplementation? Prog. Biophys. Mol. Biol. 92(1), 140-149 (2006).

3 Kjellstrom T, Butler AJ, Lucas RM, Bonita R. Public health impact of global heating due to climate change: potential effects on chronic non-communicable diseases. Int. J. Public Health 55 (2), 97-103 (2010).

4 Diffey BL. Sources and measurement of ultraviolet radiation. Methods 28(1), 4-13 (2002).

5 Liu D, Fernandez BO, Hamilton A et al. UVA irradiation of human skin vasodilates arterial vasculature and lowers blood pressure independently of nitric oxide synthase. J. Invest. Dermatol. 134(7), 1839-1846 (2014).

6 Halliday GM, Rana S. Waveband and dose dependency of sunlight-induced immunomodulation and cellular changes. Photochem. Photobiol. 84(1), 35-46 (2008).

7 Lucas RM, Norval M, Neale RE et al. The consequences for human health of stratospheric ozone depletion in association with other environmental factors. Photochem. Photobiol. Sci. 14(1), 53-87 (2015).

8 Davenport C. Multiple sclerosis from the standpoint of geographic distribution and race. Arch. Neurol. Psychiat. 8(1), 51-58 (1922).

9 Simpson S Jr., Blizzard L, Otahal P, van der Mei I, Taylor B. Latitude is significantly associated with the prevalence of multiple sclerosis: a meta-analysis. J. Neurol. Neurosurg. Psychiatry 82(10), 1132-1141 (2011).

10 Taylor BV, Lucas RM, Dear K et al. Latitudinal variation in incidence and type of first central nervous system demyelinating events. Mult. Scler. 16(4), 398-405 (2010) 
11 Ascherio A, Munger KL. Environmental risk factors for multiple sclerosis. Part I: the role of infection. Ann. Neurol. 61(4), 288-299 (2007).

12 Hewer S, Lucas R, van der Mei I, Taylor BV. Vitamin D and multiple sclerosis. J. Clin. Neurosci. 20(5), 634-641 (2013).

13 Niino M, Sato S, Fukazawa T et al. Decreased serum vitamin D levels in Japanese patients with multiple sclerosis. J. Neuroimmunol. 279, 40-45 (2015).

14 Munger KL, Levin LI, Hollis BW, Howard NS, Ascherio A. Serum 25-hydroxyvitamin D levels and risk of multiple sclerosis. JAMA 296(23), 2832-2838 (2006).

15 Lucas RM, Ponsonby AL, Dear K et al. Sun exposure and vitamin $\mathrm{D}$ are independent risk factors for CNS demyelination. Neurology 76(6), 540-548 (2011).

-. The first observational study in humans to indicate independent effects of sun exposure and vitamin $\mathrm{D}$ on risk of multiple sclerosis (MS).

16 Willer CJ, Dyment DA, Sadovnick AD, Rothwell PM, Murray TJ, Ebers GC. Timing of birth and risk of multiple sclerosis: population based study. BMJ 330(7483), 120 (2005).

17 Staples J, Ponsonby AL, Lim L. Low maternal exposure to ultraviolet radiation in pregnancy, month of birth, and risk of multiple sclerosis in offspring: longitudinal analysis. BMJ 340, c1640 (2010).

- Paper suggests the importance of intrauterine exposure to UV radiation on the subsequent risk of MS.

18 Bjornevik K, Riise T, Casetta I et al. Sun exposure and multiple sclerosis risk in Norway and Italy: the ENVIMS study. Mult. Scler. 20(8), 1042-1049 (2014).

19 van der Mei IA, Ponsonby AL, Dwyer T et al. Past exposure to sun, skin phenotype, and risk of multiple sclerosis: case-control study. BMJ 327(7410), 316-321 (2003).

20 Kampman MT, Wilsgaard T, Mellgren SI. Outdoor activities and diet in childhood and adolescence relate to MS risk above the Arctic circle. J. Neurol. 254(4), 471-477 (2007).

21 Ueda P, Rafatnia F, Baarnhielm M et al. Neonatal vitamin D status and risk of multiple sclerosis. Ann. Neurol. 76(3), 338-346 (2014).

22 Salzer J, Hallmans G, Nystrom M, Stenlund H, Wadell G, Sundstrom P. Vitamin D as a protective factor in multiple sclerosis. Neurology 79(21), 2140-2145 (2012).

23 Mirzaei F, Michels KB, Munger K et al. Gestational vitamin D and the risk of multiple sclerosis in offspring. Ann.

Neurol. 70 (1), 30-40 (2011).

24 Munger KL, Zhang SM, O’Reilly E et al. Vitamin D intake and incidence of multiple sclerosis. Neurology 62(1), 60-65 (2004).

25 Kalman B, Toldy E. Genomic binding sites and biological effects of the vitamin D VDR complex in multiple sclerosis. Neuromol. Med. 16(2), 265-279 (2014).

26 Ramagopalan SV, Maugeri NJ, Handunnetthi $\mathrm{L}$ et al. Expression of the multiple sclerosisassociated MHC class II allele HLADRB1*1501 is regulated by vitamin D. PLoS Genet. 5(2), e1000369 (2009).

- Evidence of a role of vitamin D through genetic factors is specific to vitamin $\mathrm{D}$ and not other sun exposure-related pathways.

27 Zhuang JC, Huang ZY, Zhao GX, Yu H, Li ZX, Wu ZY. Variants of CYP27b1 are associated with both multiple sclerosis and neuromyelitis optica patients in Han Chinese population. Gene 557(2), 236-239 (2015).

28 International Multiple Sclerosis Genetics Consortium, Wellcome Trust Case Control Consortium, Sawcer S et al. Genetic risk and a primary role for cell-mediated immune mechanisms in multiple sclerosis. Nature 476(7359), 214-219 (2011).

29 Handel AE, Sandve GK, Disanto G et al. Vitamin D receptor chip-seq in primary CD4 ${ }^{+}$cells: relationship to serum 25-hydroxyvitamin D levels and autoimmune disease. BMC Med. 11, 163 (2013).

30 Simon KC, Munger KL, Xing Y, Ascherio A. Polymorphisms in vitamin D metabolism related genes and risk of multiple sclerosis. Mult. Scler. 16(2), 133-138 (2010).

31 Garcia-Martin E, Agundez JA, Martinez C et al. Vitamin D3 receptor (VDR) gene rs2228570 (Fok1) and rs731236 (Taq1) variants are not associated with the risk for multiple sclerosis: results of a new study and a meta-analysis. PLoS ONE 8(6), e65487 (2013).

32 Narooie-Nejad M, Moossavi M, Torkamanzehi A, Moghtaderi A. Positive association of vitamin $\mathrm{D}$ receptor gene variations with multiple sclerosis in south east Iranian population. BioMed Res. Int. 2015, 427519 (2015).

33 Narooie-Nejad M, Moossavi M, Torkamanzehi A, Moghtaderi A, Salimi S. Vitamin D receptor gene polymorphism and the risk of multiple sclerosis in south eastern Iran. J. Mol. Neurosci. 56(3), 572-576 (2015).

34 Cierny D, Michalik J, Kurca E, Dobrota D, Lehotsky J. Fokl vitamin D receptor gene polymorphism in association with multiple sclerosis risk and disability progression in Slovaks. Neurol. Res. 37(4), 301-308 (2015).

35 Tizaoui K, Kaabachi W, Hamzaoui A, Hamzaoui K. Association between vitamin D receptor polymorphisms and multiple sclerosis: systematic review and meta-analysis of case-control studies. Cell. Mol. Immunol. 12(2), 243-252 (2015).

36 Ahn J, Yu K, Stolzenberg-Solomon R et al. Genome-wide association study of circulating vitamin D levels. Hum. Mol. Genet. 19(13), 2739-2745 (2010).

37 Yousefzadeh P, Shapses SA, Wang X. Vitamin $\mathrm{D}$ binding protein impact on 25-hydroxyvitamin D levels under different physiologic and pathologic conditions. Int. J. Endocrinol. 2014, 981581 (2014).

38 Rinaldi AO, Sanseverino I, Purificato C et al. Increased circulating levels of vitamin D binding protein in MS patients. Toxins 7(1), 129-137 (2015)

39 Smolders J, Peelen E, Thewissen M, Menheere P, Damoiseaux J, Hupperts R. Circulating vitamin $\mathrm{D}$ binding protein levels are not associated with relapses or with vitamin D status in multiple sclerosis. Mult. Scler. 20(4), 433-437 (2014).

40 Martinelli V, Dalla Costa G, Colombo B et al. Vitamin D levels and risk of multiple sclerosis in patients with clinically isolated syndromes. Mult. Scler. 20(2), 147-155 (2014).

41 Ascherio A, Munger KL, White R et al. Vitamin D as an early predictor of multiple sclerosis activity and progression. JAMA Neurol. 71(3), 306-314 (2014).

42 Thouvenot E, Orsini M, Daures JP, Camu W. Vitamin D is associated with degree of disability in patients with fully ambulatory relapsing-remitting multiple sclerosis. Eur. J. Neurol. 22(3), 564-569 (2015).

43 Farsani ZS, Behmanesh M, Sahraian MA. Interleukin-10 but not transforming growth factor-betal gene expression is up-regulated by vitamin $\mathrm{D}$ treatment in multiple sclerosis patients. J. Neurol. Sci. 350(1-2), 18-23 (2015).

44 Runia TF, Neuteboom RF, De Groot CJ, De Rijke YB, Hintzen RQ. The influence of vitamin $\mathrm{D}$ on postpartum relapse and quality of life in pregnant multiple sclerosis patients. Eur. J. Neurol. 22(3), 479-484 (2015).

45 Duan S, Lv Z, Fan X et al. Vitamin D status and the risk of multiple sclerosis: a systematic review and meta-analysis. Neurosci. Lett. 570 108-113 (2014).

46 Lin R, Taylor BV, Simpson S Jr et al. Novel modulating effects of PKC family genes on 
the relationship between serum vitamin $\mathrm{D}$ and relapse in multiple sclerosis. J. Neurol. Neurosurg. Psychiatry 85(4), 399-404 (2014).

47 Lin R, Taylor BV, Simpson S Jr. et al. Association between multiple sclerosis risk-associated SNPs and relapse and disability - a prospective cohort study. Mult. Scler. 20(3), 313-321 (2014).

48 Stewart N, Simpson S Jr, Van Der Mei I et al. Interferon-beta and serum 25-hydroxyvitamin $\mathrm{D}$ interact to modulate relapse risk in MS. Neurology 79(3), 254-260 (2012).

49 Lin R, Taylor BV, Charlesworth J et al. Modulating effects of WT1 on interferon-betavitamin D association in MS. Acta Neurol. Scand. 131(4), 231-239 (2015).

50 Fyfe I. Multiple sclerosis: effects of IFN-beta treatment on vitamin D levels in multiple sclerosis are modified by genetic variants. Nat. Rev. Neurol. 10(12), 672 (2014).

51 Rosjo E, Myhr KM, Loken-Amsrud KI et al. Vitamin D status and effect of interferonbetala treatment on MRI activity and serum inflammation markers in relapsing-remitting multiple sclerosis. J. Neuroimmunol. 280, 21-28 (2015).

52 Mandia D, Ferraro OE, Nosari G, Montomoli C, Zardini E, Bergamaschi R. Environmental factors and multiple sclerosis severity: a descriptive study. Int. J. Env. Res. Public Health 11(6), 6417-6432 (2014).

53 Knippenberg S, Damoiseaux J, Bol Y et al. Higher levels of reported sun exposure, and not vitamin D status, are associated with less depressive symptoms and fatigue in multiple sclerosis. Acta Neurol. Scand. 129(2), 123-131 (2014).

54 Taylor KL, Hadgkiss EJ, Jelinek GA et al. Lifestyle factors, demographics and medications associated with depression risk in an international sample of people with multiple sclerosis. BMC Psychiatry 14(1), 327 (2014).

55 Jagannath VA, Fedorowicz Z, Asokan GV, Robak EW, Whamond L. Vitamin D for the management of multiple sclerosis. Cochrane Database Syst. Rev. (12), CD008422 (2010).

56 Derakhshandi H, Etemadifar M, Feizi A et al. Preventive effect of vitamin $\mathrm{D}_{3}$ supplementation on conversion of optic neuritis to clinically definite multiple sclerosis: a double blind, randomized, placebocontrolled pilot clinical trial. Acta Neurol. Belg. 113(3), 257-263 (2013).

57 Achiron A, Givon U, Magalashvili D et al. Effect of alfacalcidol on multiple sclerosisrelated fatigue: a randomized, double-blind placebo-controlled study. Mult. Scler. 21(6), 767-775 (2014).
58 Bhargava P, Cassard S, Steele SU et al. The vitamin $\mathrm{D}$ to ameliorate multiple sclerosis (VIDAMS) trial: study design for a multicenter, randomized, double-blind controlled trial of vitamin D in multiple sclerosis. Contemp. Clin. Trials 39(2), 288-293 (2014).

59 Spelman T, Gray O, Trojano M et al. Seasonal variation of relapse rate in multiple sclerosis is latitude dependent. Ann. Neurol. 76(6), 880-890 (2014).

60 Breuer J, Schwab N, Schneider-Hohendorf T et al. Ultraviolet B light attenuates the systemic immune response in central nervous system autoimmunity. Ann. Neurol. 75(5), 739-758 (2014).

61 Schwarz T. 25 years of UV-induced immunosuppression mediated by $\mathrm{T}$ cells - from disregarded $\mathrm{T}$ suppressor cells to highly respected regulatory $\mathrm{T}$ cells. Photochem. Photobiol. 84(1), 10-18 (2008).

-• An excellent summary of the effect of UV radiation on $T$ cells and immune function.

62 Gorman S, Kuritzky LA, Judge MA et al. Topically applied 1,25-dihydroxyvitamin $\mathrm{D}_{3}$ enhances the suppressive activity of $\mathrm{CD} 4{ }^{+} \mathrm{CD} 25^{+}$cells in the draining lymph nodes. J. Immunol. 179(9), 6273-6283 (2007).

63 Damian DL, Kim YJ, Dixon KM, Halliday GM, Javeri A, Mason RS. Topical calcitriol protects from UV-induced genetic damage but suppresses cutaneous immunity in humans. Exp. Dermatol. 19(8), e23-30 (2010).

64 Gruber-Wackernagel A, Bambach I, Legat FJ et al. Randomized double-blinded placebocontrolled intra-individual trial on topical treatment with a 1,25-dihydroxyvitamin $\mathrm{D}(3)$ analogue in polymorphic light eruption. $\mathrm{Br}$. J. Dermatol. 165(1), 152-163 (2011).

65 Milliken SV, Wassall H, Lewis BJ et al. Effects of ultraviolet light on human serum 25-hydroxyvitamin D and systemic immune function. J. Allergy Clin. Immunol. 129(6), 1554-1561 (2012).

66 Khoo AL, Joosten I, Michels M et al. 1,25-dihydroxyvitamin D3 inhibits proliferation but not the suppressive function of regulatory $\mathrm{T}$ cells in the absence of antigen-presenting cells. Immunology 134(4), 459-468 (2011).

67 Correale J, Ysrraelit MC, Gaitan MI. Immunomodulatory effects of vitamin $\mathrm{D}$ in multiple sclerosis. Brain 132(Pt 5), 1146-1160 (2009).

68 Yip KH, Kolesnikoff N, Yu C et al. Mechanisms of vitamin D(3) metabolite repression of IgE-dependent mast cell activation. J. Allergy Clin. Immunol. 133(5), 1356-1364, 1364 e1351-1314 (2014).

69 Biggs L, Yu C, Fedoric B, Lopez AF, Galli SJ, Grimbaldeston MA. Evidence that vitamin $\mathrm{D}$ (3) promotes mast cell-dependent reduction of chronic UVB-induced skin pathology in mice. J. Exp. Med. 207(3), 455-463 (2010).

70 Hart PH, Grimbaldeston MA, Swift GJ, Jaksic A, Noonan FP, Finlay-Jones JJ. Dermal mast cells determine susceptibility to ultraviolet B-induced systemic suppression of contact hypersensitivity responses in mice. J. Exp. Med. 187(12), 2045-2053 (1998).

71 Byrne SN, Limon-Flores AY, Ullrich SE. Mast cell migration from the skin to the draining lymph nodes upon ultraviolet irradiation represents a key step in the induction of immune suppression. J. Immunol. 180(7), 4648-4655 (2008).

72 Chacon-Salinas R, Limon-Flores AY, Chavez-Blanco AD, Gonzalez-Estrada A, Ullrich SE. Mast cell-derived IL-10 suppresses germinal center formation by affecting $\mathrm{T}$ follicular helper cell function.

J. Immunol. 186(1), 25-31 (2011).

73 Lu LF, Lind EF, Gondek DC et al. Mast cells are essential intermediaries in regulatory T-cell tolerance. Nature 442(7106), 997-1002 (2006).

74 Gauchat JF, Henchoz S, Mazzei G et al. Induction of human $\operatorname{IgE}$ synthesis in $\mathrm{B}$ cells by mast cells and basophils. Nature 365(6444), 340-343 (1993).

75 Byrne SN, Halliday GM. B cells activated in lymph nodes in response to ultraviolet irradiation or by interleukin-10 inhibit dendritic cell induction of immunity. J. Invest. Dermatol. 124(3), 570-578 (2005).

76 Matsumura Y, Byrne SN, Nghiem DX, Miyahara Y, Ullrich SE. A role for inflammatory mediators in the induction of immunoregulatory B cells. J. Immunol. 177(7), 4810-4817 (2006).

77 Mauri C, Bosma A. Immune regulatory function of B cells. Ann. Rev. Immunol. 30, 221-241 (2012).

78 Byrne SN, Ahmed J, Halliday GM. Ultraviolet $\mathrm{B}$ but not $\mathrm{A}$ radiation activates suppressor B cells in draining lymph nodes. Photochem. Photobiol. 81(6), 1366-1370 (2005).

79 Walterscheid JP, Nghiem DX, Kazimi N et al. Cis-urocanic acid, a sunlight-induced immunosuppressive factor, activates immune suppression via the 5-HT2a receptor. Proc. Natl Acad. Sci. USA 103(46), 17420-17425 (2006). 
80 Chen S, Sims GP, Chen XX, Gu YY, Chen S, Lipsky PE. Modulatory effects of 1,25-dihydroxyvitamin $\mathrm{D}_{3}$ on human $\mathrm{B}$ cell differentiation. J. Immunol. 179(3), 1634-1647 (2007).

81 Heine G, Niesner U, Chang HD et al. 1,25-dihydroxyvitamin $\mathrm{D}$ (3) promotes IL-10 production in human B cells. Eur. J. Immunol. 38(8), 2210-2218 (2008).

82 Duddy M, Niino M, Adatia F et al. Distinct effector cytokine profiles of memory and naive human B cell subsets and implication in multiple sclerosis. J. Immunol. 178(10), 6092-6099 (2007).

83 Knippenberg S, Peelen E, Smolders J et al. Reduction in IL-10 producing B cells $\left(\mathrm{B}_{\text {reg }}\right)$ in multiple sclerosis is accompanied by a reduced naive/memory $\mathrm{B}_{\text {reg }}$ ratio during a relapse but not in remission.

J. Neuroimmunol. 239(1-2), 80-86 (2011).

84 Von Budingen HC, Bar-Or A, Zamvil SS. $\mathrm{B}$ cells in multiple sclerosis: connecting the dots. Curr. Opin. Immunol. 23(6), 713-720 (2011).

85 Knippenberg S, Smolders J, Thewissen M et al. Effect of vitamin $\mathrm{D}$ (3) supplementation on peripheral $\mathrm{B}$ cell differentiation and isotype switching in patients with multiple sclerosis. Mult. Scler. 17(12), 1418-1423 (2011).

86 Hemmer B, Kerschensteiner M, Korn T. Role of the innate and adaptive immune responses in the course of multiple sclerosis. Lancet Neurol. 14(4), 406-419 (2015).

87 Mohammad MG, Tsai VW, Ruitenberg MJ et al. Immune cell trafficking from the brain maintains CNS immune tolerance. J. Clin. Invest. 124(3), 1228-1241 (2014).

88 Pashenkov M, Huang YM, Kostulas V, Haglund M, Soderstrom M, Link H. Two subsets of dendritic cells are present in human cerebrospinal fluid. Brain 124(Pt 3), 480-492 (2001).

89 Adorini L, Penna G, Giarratana N et al. Dendritic cells as key targets for immunomodulation by vitamin $\mathrm{D}$ receptor ligands. J. Steroid Biochem. Mol. Biol. 89-90 (1-5), 437-441 (2004).

90 Deluca HF, Plum LA. Vitamin D deficiency diminishes the severity and delays onset of experimental autoimmune encephalomyelitis. Arch Biochem. Biophys. 513(2), 140-143 (2011).

91 Fernandes De Abreu DA, Ibrahim EC, Boucraut J, Khrestchatisky M, Feron F. Severity of experimental autoimmune encephalomyelitis is unexpectedly reduced in mice born to vitamin D-deficient mothers. J. Steroid Biochem. Mol. Biol. 121(1-2), 250-253 (2010).

92 Wang Y, Marling SJ, Zhu JG, Severson KS, Deluca HF. Development of experimental autoimmune encephalomyelitis (EAE) in mice requires vitamin $\mathrm{D}$ and the vitamin $\mathrm{D}$ receptor. Proc. Natl. Acad. Sci. USA 109 (22), 8501-8504 (2012).

93 Van Luijn MM, Kreft KL, Jongsma ML et al. Multiple sclerosis-associated CLEC16a controls HLA class II expression via late endosome biogenesis. Brain 138(Pt6), 1531-1547 (2015).

94 Shahijanian F, Parnell GP, McKay FC et al. The CYP27b1 variant associated with an increased risk of autoimmune disease is underexpressed in tolerizing dendritic cells. Hum. Mol. Genet. 23(6), 1425-1434 (2014).

95 Sanseverino I, Rinaldi AO, Purificato C et al. $\mathrm{CCl} 2$ induction by $1,25(\mathrm{OH})_{2} \mathrm{D}_{3}$ in dendritic cells from healthy donors and multiple sclerosis patients. J. Steroid Biochem. Mol. Biol. 144(Pt A), 102-105 (2014).

96 Hauser SL, Weiner HL, Che M, Shapiro ME, Gilles F, Letvin NL. Prevention of experimental allergic encephalomyelitis (EAE) in the SJL/J mouse by whole body ultraviolet irradiation. J. Immunol. 132(3), 1276-1281 (1984).

97 Becklund BR, Severson KS, Vang SV, Deluca HF. UV radiation suppresses experimental autoimmune encephalomyelitis independent of vitamin D production. Proc. Natl. Acad. Sci. USA 107(14), 6418-6423 (2010).

98 Ng RL, Bisley JL, Gorman S, Norval M, Hart $\mathrm{PH}$. Ultraviolet irradiation of mice reduces the competency of bone marrow-derived CD11 ${ }^{+}$ cells via an indomethacin-inhibitable pathway. J. Immunol. 185(12), 7207-7215 (2010).

$99 \mathrm{Ng}$ RL, Scott NM, Strickland DH et al. Altered immunity and dendritic cell activity in the periphery of mice after long-term engraftment with bone marrow from ultraviolet-irradiated mice. J. Immunol. 190 (11), 5471-5484 (2013).

100 Scott NM, Ng RL, Gorman S, Norval M, Waithman J, Hart PH. Prostaglandin E2 imprints a long-lasting effect on dendritic cell progenitors in the bone marrow. J. Leuk. Biol. 95(2), 225-232 (2014).

- Paper provides a pathway whereby UV radiation affects dendritic cell progenitos and evidence of a long lasting effect.

101 Mcloone P, Simics E, Barton A, Norval M, Gibbs NK. An action spectrum for the production of cis-urocanic acid in human skin in vivo. J. Invest. Dermatol. 124(5), 1071-1074 (2005).
102 Gibbs NK, Tye J, Norval M. Recent advances in urocanic acid photochemistry, photobiology and photoimmunology. Photochem. Photobiol. Sci. 7(6), 655-667 (2008).

103 Beissert S, Ruhlemann D, Mohammad T et al. IL-12 prevents the inhibitory effects of cis-urocanic acid on tumor antigen presentation by langerhans cells: implications for photocarcinogenesis. J. Immunol. 167(11), 6232-6238 (2001).

104 Gruner S, Diezel W, Stoppe H, Oesterwitz H, Henke W. Inhibition of skin allograft rejection and acute graft-versus-host disease by cis-urocanic acid. J. Invest. Dermatol. 98(4), 459-462 (1992).

105 Noonan FP, De Fabo EC. Immunosuppression by ultraviolet $\mathrm{B}$ radiation: initiation by urocanic acid. Immunol. Today 13(7), 250-254 (1992).

106 Norval M, Simpson TJ, Bardshiri E, Howie SE. Urocanic acid analogues and the suppression of the delayed type hypersensitivity response to herpes simplex virus. Photochem. Photobiol. 49(5), 633-639 (1989).

107 Albert E, Walker J, Thiesen A, Churchill T, Madsen K. Cis-urocanic acid attenuates acute dextran sodium sulphate-induced intestinal inflammation. PLoS ONE 5(10), e13676 (2010).

108 Correale J, Farez MF. Modulation of multiple sclerosis by sunlight exposure: role of cis-urocanic acid. J. Neuroimmunol. 261(1-2), 134-140 (2013).

- The first demonstration that cis-UCA may have a role in UV-induced immunosuppression.

109 Holan V, Kuffova L, Zajicova A et al. Urocanic acid enhances IL-10 production in activated CD4 ${ }^{+}$T cells. J. Immunol. 161(7), 3237-3241 (1998).

110 Woodward EA, Prele CM, Finlay-Jones JJ, Hart $\mathrm{PH}$. The receptor for cis-urocanic acid remains elusive. J. Invest. Dermatol. 126(5), 1191-1193 (2006).

111 Yamaguchi T, Hiromasa K, Kabashima-Kubo R, Yoshioka M, Nakamura M. Galectin-7, induced by cis-urocanic acid and ultraviolet $\mathrm{B}$ irradiation, down-modulates cytokine production by T lymphocytes. Exp. Dermatol. 22(12), 840-842 (2013).

112 Marsh-Wakefield F, Byrne SN. Photoimmunology and multiple sclerosis. Curr. Top. Behav. Neurosci. doi:10.1007/7854_2014_359 (2015) (Epub ahead of print).

-. Excellent summary and review of the role of UV-induced immunosuppression in multiple sclerosis. 
113 Hiraguchi $Y$, Tanida $\mathrm{H}$, Sugimoto $\mathrm{M}$ et al. 1,25-dihydroxyvitamin D3 upregulates functional $\mathrm{C}-\mathrm{x}-\mathrm{C}$ chemokine receptor type 4 expression in human eosinophils. Int. Arch. Allergy Immunol. 158(Suppl. 1), 51-57 (2012).

114 Byrne SN, Beaugie C, O'sullivan C, Leighton $S$, Halliday GM. The immune-modulating cytokine and endogenous alarmin interleukin-33 is upregulated in skin exposed to inflammatory UVB radiation. Am. J. Pathol. 179(1), 211-222 (2011).

115 Pfeffer PE, Chen YH, Woszczek G et al. Vitamin D enhances production of soluble ST2, inhibiting the action of IL-33. J. Allergy Clin. Immunol. 135(3), 824-827 e823 (2015).

116 Chacón-Salinas R, Chen L, Chávez-Blanco AD, Limón-Flores AY, Ma Y and Ullrich SE. An essential role for platelet-activating factor in activating mast cell migration following ultraviolet irradiation. J. Leukoc. Biol. 95(1), 139-148 (2014).

117 Chu CC, Ali N, Karagiannis P et al. Resident CD141 (BDCA3) dendritic cells in human skin produce IL-10 and induce regulatory $\mathrm{T}$ cells that suppress skin inflammation. J. Exp. Med. 209(5), 935-945 (2012).

118 Macleod AS, Rudolph R, Corriden R, Ye I, Garijo O, Havran WL. Skin-resident T cells sense ultraviolet radiation-induced injury and contribute to DNA repair.

J. Immunol. 192(12), 5695-5702 (2014).

119 Argaw AT, Zhang Y, Snyder BJ et al. IL-1beta regulates blood-brain barrier permeability via reactivation of the hypoxia-angiogenesis program. J. Immunol. 177(8), 5574-5584 (2006).

120 Petit-Frere C, Clingen PH, Grewe M et al. Induction of interleukin- 6 production by ultraviolet radiation in normal human epidermal keratinocytes and in a human keratinocyte cell line is mediated by DNA damage. J. Invest. Dermatol. 111(3), 354-359 (1998).

121 Erta M, Quintana A, Hidalgo J. Interleukin-6, a major cytokine in the central nervous system. Int. J. Biol. Sci. 8(9), 1254-1266 (2012)

122 Fukuoka M, Ogino Y, Sato H, Ohta T, Komoriya K. Regulation of RANTES and IL-8 production in normal human dermal fibroblasts by active vitamin $\mathrm{D}_{3}$ (tacalcitol). Br. J. Pharmacol. 124(7), 1433-1438 (1998).

123 Lund BT, Ashikian N, Ta HQ et al. Increased CXCL8 (IL-8) expression in multiple sclerosis. $J$. Neuroimmunol. 155(1-2), 161-171 (2004).

124 Mostafa W, Hegazy R. Vitamin D and the skin: focus on a complex relationship. J. $A d v$. Res. doi:10.1016/j.jare.2014.01.011 (2014) (Epub ahead of print).

125 Shiomi A, Usui T. Pivotal roles of GM-CSF in autoimmunity and inflammation. Mediators Inflamm. 568543 doi: 10.1155/2015/568543 (2015) (Epub ahead of print).

126 Imokawa G, Ishida K. Biological mechanisms underlying the ultraviolet radiation-induced formation of skin wrinkling and sagging I: reduced skin elasticity, highly associated with enhanced dermal elastase activity, triggers wrinkling and sagging. Int. J. Mol. Sci. 16(4), 7753-7775 (2015).

127 Corsini E, Bruccoleri A, Marinovich M, Galli CL. In vitro mechanism(s) of ultraviolet-induced tumor necrosis factor-alpha release in a human keratinocyte cell line. Photodermatol. Photoimmunol. Photomed. 11(3), 112-118 (1995).

128 Christophi GP, Gruber RC, Panos M, Christophi RL, Jubelt B, Massa PT. Interleukin-33 upregulation in peripheral leukocytes and CNS of multiple sclerosis patients. Clin. Immunol. 142(3), 308-319 (2012).

129 Jiang HR, Milovanovic M, Allan D et al. IL-33 attenuates EAE by suppressing IL-17 and IFN-gamma production and inducing alternatively activated macrophages. Eur. J. Immunol. 42(7), 1804-1814 (2012).

130 Friedrich M, Holzmann R, Sterry W et al. Ultraviolet $B$ radiation-mediated inhibition of interferon-gamma-induced keratinocyte activation is independent of interleukin-10 and other soluble mediators but associated with enhanced intracellular suppressors of cytokine-signaling expression. J. Invest. Dermatol. 121(4), 845-852 (2003).

131 Zhu S, Qian Y. IL-17/IL-17 receptor system in autoimmune disease: Mechanisms and therapeutic potential. Clin. Sci. 122(11), 487-511 (2012).

132 Khalil Z, Townley SL, Grimbaldeston MA, Finlay-Jones JJ, Hart PH. Cis-urocanic acid stimulates neuropeptide release from peripheral sensory nerves. J. Invest. Dermatol. 117(4), 886-891 (2001).

133 Scholzen TE, Brzoska T, Kalden DH et al. Effect of ultraviolet light on the release of neuropeptides and neuroendocrine hormones in the skin: mediators of photodermatitis and cutaneous inflammation. J. Investig. Dermatol. Symp. Proc. 4(1), 55-60 (1999). 